Hong, Seung Ho; Sturm, Terry W.

Physical Modeling of Abutment Scour for Overtopping, Submerged Orifice, and Free Surface Flows

Verfügbar unter / Available at:

https://hdl.handle.net/20.500.11970/100278

Vorgeschlagene Zitierweise / Suggested citation:

Hong, Seung Ho; Sturm, Terry W. (2010): Physical Modeling of Abutment Scour for Overtopping, Submerged Orifice, and Free Surface Flows. In: Burns, Susan E.; Bhatia, Shobha K.; Avila, Catherine M. C.; Hunt, Beatrice E. (Hg.): Proceedings 5th International Conference on Scour and Erosion (ICSE-5), November 7-10, 2010, San Francisco, USA. Reston, Va.: American Society of Civil Engineers. S. 590-598. 


\title{
Physical Modeling of Abutment Scour for Overtopping, Submerged Orifice, and Free Surface Flows
}

\author{
Seung Ho Hong ${ }^{1}$ and T. W. Sturm ${ }^{2}$, M. ASCE
}

${ }^{1}$ Grad. Research Asst., School of Civil and Environmental Engineering, Georgia Institute of Technology, 790 Atlantic Dr, Atlanta, Georgia 30332; email: gtg002q@mail.gatech.edu

${ }^{2}$ Professor, School of Civil and Environmental Engineering, Georgia Institute of Technology, 790 Atlantic Dr, Atlanta, Georgia 30332; PH (404) 894-2218; email: tsturm@ce.gatech.edu

\begin{abstract}
Recent flooding in the Atlanta metro area in Georgia, USA in September 2009 resulted in extensive damage to numerous bridges due to overtopping which caused abutment scour and failure of the approach embankment in some instances. At several locations, the 500-year flood level was exceeded. A laboratory study was conducted to compare characteristics of abutment scour for free-surface flow, submerged orifice flow and overtopping flow cases. Detailed bed scour contours under and downstream of the bridge as well as velocity distributions were measured for a model bridge with a set-back abutment in the floodplain of a compound channel. The channel bathymetry and bridge geometry were based on a typical bridge in the Piedmont region of Georgia. The embankment was constructed of an erodible core covered with rock riprap protection. Results showed that maximum abutment scour is a combination of local turbulence and flow contraction effects and has different magnitudes depending on the flow types (free-surface, submerged orifice, and overtopping) that produce unique flow fields through the bridge in the vicinity of the abutment.
\end{abstract}

\section{INTRODUCTION}

Failure of bridges due to bridge foundation scour during floods has been well documented (Parola et al. 1998, Richardson and Davis 2001, Morris and Pagan-Ortiz 1999). In many cases, the cause of failure has been classified as abutment scour although there is no clear agreement on its definition. In current scour prediction methodology as recommended by the report HEC-18 (Richardson and Davis 2001), abutment scour is treated as local scour near the abutment while contraction scour is considered to be scour that occurs across the entire cross-section, and the two estimates of maximum scour depth are added to obtain an estimate of total scour at the abutment. In contrast, laboratory studies by Sturm $(1999,2006)$, Ettema et al. (2006), and Ettema et al. (2008) on long abutments terminating on the floodplain of compound channels, for example, have predicted abutment scour depth as a multiplying factor times the idealized contraction scour depth as suggested by Laursen (1963), but all of these studies have focused on the case of free-surface flow. The latter studies by Ettema et al. are unique in that they include an erodible embankment instead of a fixed embankment that is more representative of a sheet-pile or riprap-protected abutment. Further confusing the issue of the definition 
of abutment scour is that extreme hydrologic events of the order of the 500-year or larger event can often result in submerged orifice flow, or embankment and bridge overtopping flow in combination with submerged orifice flow. Submergence of the upstream face of the bridge produces vertical flow contraction in addition to existing lateral flow contraction caused by the embankment on the floodplain. The result is a complex flow field in the vicinity of the abutment that results in a scour bathymetry having characteristics of vertical and lateral flow contraction in combination with local turbulence effects associated with the horseshoe vortex and a separated shear zone near the face of the abutment.

Occurrences of floods of extreme magnitude may seem to be so rare as to obviate the necessity of analysis but in 1994 (Tropical Storm Alberto) and again in 2009 , such extreme floods occurred in Georgia resulting in widespread damage and closure of bridges as well as loss of life. A typical embankment failure due to bridge overtopping during flooding in September of 2009 is shown in Figure 1. This flood event resulted from precipitation in the Atlanta metro area that exceeded the 500-year recurrence interval (personal communication, Mark Landers, USGS). Flow coming from the left floodplain as well as overtopping of the bridge severely eroded the left embankment, exposed the abutment and resulted in the approach span to the bridge deck falling into the stream.

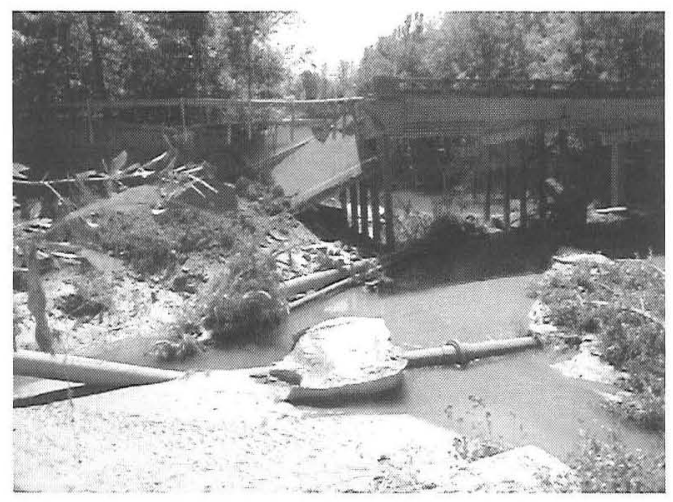

Figure 1. Example of abutment failure due to bridge overtopping

Given that embankment overtopping can and does occur, and may even be allowed to occur if the abutment structure itself is designed to withstand failure, this study is a preliminary consideration of the types of scour that are present in such instances. For this purpose, a model of a typical bridge in the Georgia Piedmont with an embankment terminating on the floodplain is used to investigate different modes of scour in free-surface, submerged orifice, and overtopping flows. Previously, this model was used to develop a laboratory modeling strategy for scour verified by comparisons with field measurements of scour during an historic flood associated with Tropical Storm Alberto (Hong and Sturm 2009). 


\section{EXPERIMENTAL INVESTIGATION}

The bridge chosen to be modeled in this study is located near Macon, Georgia on the Towaliga River, which is a tributary of the Ocmulgee River. The bridge crosses between two bluffs with a solid rock outcropping forming the steep right bank just downstream of the bridge while a floodplain exists on the left side of the river. The drainage area of the river at the bridge is $816 \mathrm{~km}^{2}$. Discharge was estimated as $1700 \mathrm{~m}^{3} / \mathrm{s}$ by the U. S. Geological Survey for Tropical Storm Alberto (Stamey 1996). A model of the SR 42 bridge and the Towaliga River bathymetry was built in the Georgia Tech Hydraulics Laboratory at a scale of 1:60 as shown in Figure 2. Velocities and scour depths were measured in order to compare three types of flow: free-surface flow, submerged orifice flow and overtopping flow.

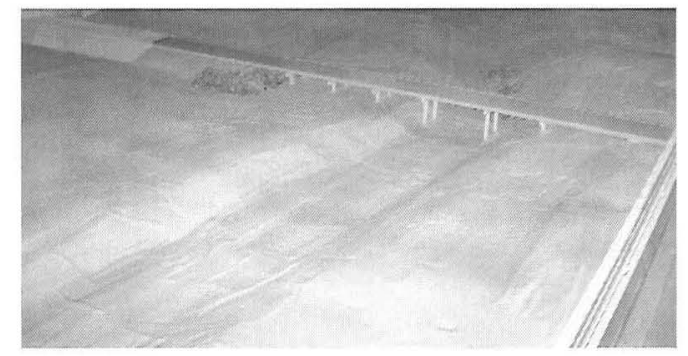

\section{Figure 2. Laboratory model of Towaliga River bridge}

The physical model of the Towaliga River Bridge was built inside a $4.2 \mathrm{~m}$ wide by $24.2 \mathrm{~m}$ long horizontal flume. The approach channel upstream of the bridge was $7.3 \mathrm{~m}$ long followed by a working mobile-bed section with a length of approximately $6.1 \mathrm{~m}$ in which the bridge model was placed. Templates were utilized to reproduce the channel bathymetry. The embankment model was constructed as an erodible fill with rock riprap protection in order to reproduce the influence of erosion of the end roll on the abutment and pier scour in the region of the toe of the embankment (Ettema et al. 2006). The erodible embankment was carefully compacted by hand and covered with riprap before putting the removable model roadway and bridge deck in place. This approach was successful in maintaining the general integrity of the embankment during overtopping as was observed in the prototype.

The water supply to the flume was provided from a large constant-head tank through a $30.5 \mathrm{~cm}$ diameter pipe that can deliver a maximum discharge of $0.3 \mathrm{~m}^{3} / \mathrm{s}$ to the head box of the flume. In the supply pipe, discharge was measured by a magnetic flow meter with an uncertainty of $\pm 0.001 \mathrm{~m}^{3} / \mathrm{s}$. A flow diffuser, overflow weir, and baffles in the flume head box produced stilling of the inflow and a uniform flume inlet velocity distribution. A flap tailgate controlled the tailwater elevation.

Approach velocities were measured with a SonTek $16 \mathrm{MHz}$ acoustic Doppler velocimeter $(\mathrm{ADV})$ that was attached to an instrument carriage. A 3D down-looking probe was used to measure velocity profiles across the deeper portions of the cross section while a $2 \mathrm{D}$ side-looking probe was selected to measure velocity profiles in the 
shallow floodplain areas. The water depth and bed elevations before and after scouring were measured by a point gauge and the ADV with an uncertainty of \pm 1 $\mathrm{mm}$. The sampling frequency of the ADV was chosen to be $25 \mathrm{~Hz}$ with a sampling duration of 2 minutes at each measuring location.

Each of the pier bents consists of two in-line rectangular columns having a width, $b$, of $0.91 \mathrm{~m}$. Abutment or end bents were also modeled and buried in the erodible embankment which was protected by rock riprap. The bridge deck was made removable for scour measurements. The mobile bed sediment was a uniform sand with $d_{50}=0.53 \mathrm{~mm}$. Further details on the experimental setup and the modeling methodology can be found in Lee et al. 2004, Hong et al. 2009, Lee and Sturm 2009.

\section{EXPERIMENTAL PROGRAM}

Experimental conditions for Runs 10-14 are summarized in Table 1. Preliminary HEC-RAS modeling indicated that the maximum velocity under the bridge in the left floodplain would occur at $Q=1275 \mathrm{~m}^{3} / \mathrm{s}$ with subsequent increases in discharge contributing primarily to overtopping relief. On the other hand, submerged orifice flow was observed to occur first at $Q=1048 \mathrm{~m}^{3} / \mathrm{s}$ as $Q$ increased. Experimental Runs 10 and 14 were conducted at $Q=1048 \mathrm{~m}^{3} / \mathrm{s}$ with the same tailwater elevation but with and without the bridge deck in place in order to compare submerged orifice flow and free surface flow. The discharge was increased to 1275 $\mathrm{m}^{3} / \mathrm{s}$ in Run 11 to consider the case of initial overtopping with a shallow flow depth on the deck. In Run 14, discharge was increased to $1472 \mathrm{~m}^{3} / \mathrm{s}$ for deeper overtopping and then compared with free surface flow at the same discharge in Run 13 by removing the deck. In each case, the tailwater appropriate to the given discharge was set to coincide with the field tailwater rating curve.

Table 1. Experimental conditions

( $Q=$ discharge, $V_{1 m}=$ mean approach flow velocity in main channel, $V_{c m}=$ critical velocity in main channel, $V_{1 f}=$ mean approach flow velocity in floodplain, $V_{c f}=$ critical velocity in floodplain, $W . S_{._{d}}=$ water surface elevation downstream of bridge)

\begin{tabular}{|c|c|c|c|c|c|c|c|c|c|}
\hline Run & $\underset{\left(\mathrm{m}^{3} / \mathrm{s}\right)}{Q}$ & $\begin{array}{c}V_{1 m} \\
(\mathrm{~m} / \mathrm{s})\end{array}$ & $\begin{array}{c}V_{c m} \\
(\mathrm{~m} / \mathrm{s})\end{array}$ & $\frac{V_{1 m}}{V_{c m}}$ & $\begin{array}{c}V_{1 f} \\
(\mathrm{~m} / \mathrm{s})\end{array}$ & $\begin{array}{c}V_{c f} \\
(\mathrm{~m} / \mathrm{s})\end{array}$ & $\frac{V_{1 f f}}{V_{c f}}$ & $\begin{array}{c}W . S_{._{d}} \\
(\mathrm{~m})\end{array}$ & Condition \\
\hline 10 & 1,048 & 0.98 & 2.44 & 0.402 & 0.75 & 2.26 & 0.333 & 134.29 & $\begin{array}{l}\text { Submerged } \\
\text { orifice flow }\end{array}$ \\
\hline 14 & 1,048 & 0.98 & 2.44 & 0.402 & 0.75 & 2.26 & 0.333 & 134.29 & Free flow \\
\hline 11 & 1,275 & 1.00 & 2.49 & 0.402 & 0.83 & 2.31 & 0.359 & 134.47 & $\begin{array}{l}\text { Overtopping } \\
\text { flow }\end{array}$ \\
\hline 12 & 1,472 & 1.05 & 2.48 & 0.425 & 0.90 & 2.31 & 0.390 & 135.93 & $\begin{array}{c}\text { Overtopping } \\
\text { flow }\end{array}$ \\
\hline 13 & 1,472 & 1.05 & 2.48 & 0.425 & 0.90 & 2.31 & 0.390 & 135.93 & Free flow \\
\hline
\end{tabular}




\section{EXPERIMENTAL RESULTS}

The velocity distribution at the approach flow section is shown in Figure 3 for Run 10 in submerged orifice flow. The velocities are higher in the main channel than the floodplain as expected for an overbank flow, but the relative difference decreases as the discharge increases as observed in Table 1 by comparing $V_{1 m}$ and $V_{1 f}$.

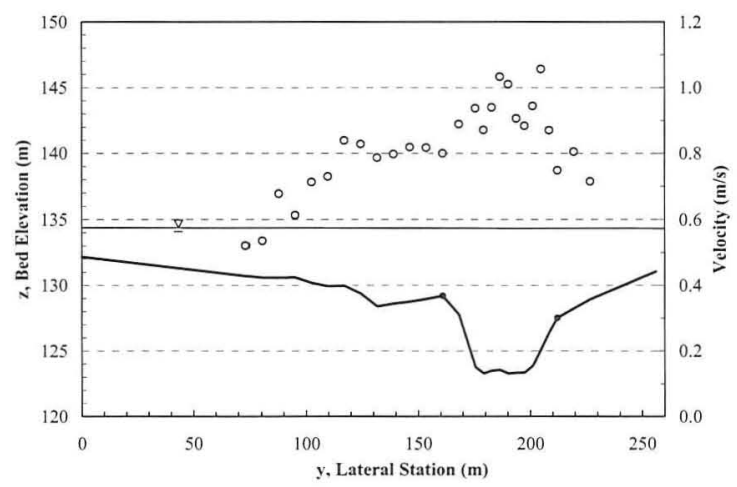

Figure 3. Measured velocity distribution in main channel and floodplain at bridge approach section for Run 10.

For each experimental condition, the scour experiments were run continuously for approximately five days to reach equilibrium. At the end of the scour experiment, the bed elevations were measured at six cross sections from the upstream to the downstream face of the bridge. The bed elevation data were adjusted to remove local pier scour (Hong et al. 2006), and the average floodplain elevation at each cross section was computed and plotted as a function of the streamwise coordinate through the bridge as shown in Figure 4. For both free-surface flow and submerged orifice flow with and without overtopping, the average floodplain contraction component of abutment scour increases with the streamwise coordinate through the bridge. The maximum value occurs near the second pier for free surface flow (Runs 13 and 14), while for submerged flows (Runs 10 and 12) it is located immediately downstream of the bridge, although a value similar to the maximum also occurs for overtopping flow at a distance of approximately 60 percent of the flow distance through the bridge. It is also clear from Figure 4 that submergence and overtopping add a significant increment of scour to the free-surface flow cases which include only the lateral contraction effect of the embankment. The largest mean floodplain scour depths through the bridge are observed for Run 12 at the maximum flow rate with overtopping.

The mean floodplain flow depth under the bridge after scour was obtained from a spatial integration of the bed profiles in Figure 4 relative to the water surface elevation. The mean depth values are given as $Y_{2 f c}$ in Table 2 and nondimensionalized in terms of the approach flow depth on the floodplain, $Y_{1 f}$. The value of $Y_{2 f c}$ represents 


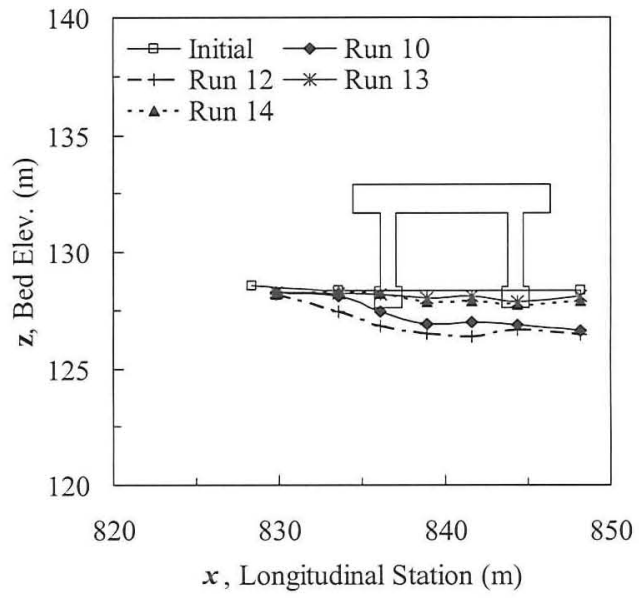

Figure 4. Mean floodplain bed elevations under the bridge after pier scour adjustment

a mean contraction/abutment scour depth on the floodplain caused by lateral flow contraction due to the floodplain flow being blocked by the embankment and forced through the bridge opening, and by vertical flow contraction in the case of submergence and overtopping. In addition to $Y_{2 f c}$, the local maximum flow depth $Y_{2 f \max }$ was determined after removal of the local pier scour from the bed elevation data and is reported in Table 2. The excess of $Y_{2 f m a x}$ relative to $Y_{2 f c}$ is the local scour contribution to abutment scour that can be attributed to the turbulence structures induced by flow separation including the horseshoe vortex and shear zone vortices around the nose of the abutment.

The dimensionless scour ratios $Y_{2 f c} / Y_{1 f}$ and $Y_{2 f \max } / Y_{1 f}$ from Table 2 are plotted in Figure 5 as a function of $V_{1 f} / V_{c f}$, which is the ratio of the approach flow velocity in the floodplain to the critical velocity for sediment motion. For both the maximum and mean values of $Y_{2} / Y_{1}$ there is an increase in going from submerged orifice flow to a minor overtopping flow (Run 11) followed by a decrease at the larger overtopping depth and flow as $V_{1 f} / V_{c f}$ increases. The minor overtopping flow is insufficient to provide relief from the submerged orifice flow passing through the bridge so the scour increases, but as the proportion of the flow that is overtopping increases at the larger overtopping flow rate, there is a corresponding decrease in scour depth through the bridge. The maximum abutment scour ratio is approximately a constant of 1.2 times the contribution of the contraction scour ratio to abutment scour; that is

$$
\frac{Y_{2 f \max }}{Y_{1 f}} \approx 1.2 \frac{Y_{2 f c}}{Y_{1 f}}
$$


Table 2. Experimental results for mean and maximum flow depths after scour ( $Q$ =discharge, $V_{1 f}=$ approach flow velocity in floodplain, $V_{c f}=$ critical velocity in floodplain, $Y_{1 f}=$ approach flow depth in floodplain, $Y_{2 f c}=$ mean contraction flow depth under bridge after pier scour adjustment, $Y_{2 f \max }=$ flow depth at point of maximum abutment scour)

\begin{tabular}{|c|c|c|c|c|c|c|c|}
\hline n $\underset{\left(\mathrm{m}^{3} / \mathrm{s}\right)}{\frac{Q}{n^{2}}}$ & $\frac{V_{1 f}}{V_{c f}}$ & $\begin{array}{l}Y_{1 f} \\
(\mathrm{~m})\end{array}$ & $\begin{array}{l}Y_{2 f c} \\
(\mathrm{~m})\end{array}$ & $\begin{array}{l}Y_{2 f \max } \\
(\mathrm{m})\end{array}$ & $\frac{Y_{2 f c}}{Y_{1 f}}$ & $\frac{Y_{2 f \max }}{Y_{1 f}}$ & $\begin{array}{c}\text { Flow } \\
\text { Condition }\end{array}$ \\
\hline
\end{tabular}

\begin{tabular}{ccccccccc}
\hline 10 & 1,048 & 0.333 & 5.126 & 7.312 & 9.040 & 1.426 & 1.763 & $\begin{array}{c}\text { Submerged orifice } \\
\text { flow }\end{array}$ \\
14 & 1,048 & 0.333 & 5.126 & 6.410 & 7.855 & 1.250 & 1.532 & Free flow \\
11 & 1,275 & 0.359 & 5.906 & 9.894 & 12.116 & 1.675 & 2.052 & Overtopping flow \\
12 & 1,472 & 0.390 & 5.946 & 9.339 & 11.083 & 1.571 & 1.864 & Overtopping flow \\
13 & 1,472 & 0.390 & 5.946 & 7.861 & 9.153 & 1.322 & 1.539 & Free flow \\
\hline
\end{tabular}

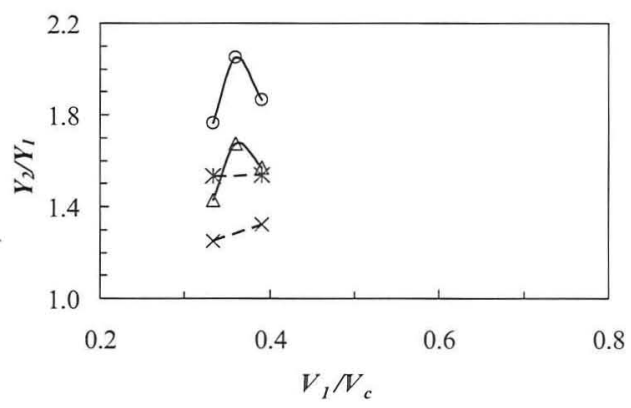

-Max. Abut. Scour (Subm.)
- Mean Cont./Abut. Scour (Subm.)
- * Max. Abut. Scour(Free)
- - Mean Cont./Abut. Scour (Free)

Figure 5. Maximum and mean relative flow depth ratios after scour for submerged and overtopping flow vs. free-surface flow 
In other words, Eq. 1 states that the maximum abutment scour is a multiple of the mean flow-contraction contribution. Eq. 1 also holds for the maximum and mean depth ratios for the free-surface flow cases shown in Figure 5. The ratio of 1.2 in Eq. 1 is not necessarily expected to be a constant because this study considers only a fixed embankment length with a relatively small variation in the degree of flow contraction; rather, it is a confirmation that total abutment scour can be considered a multiple of contraction scour effects instead of an addition of local and contraction scour components that are incorrectly assumed to be independent. In this analysis, it is the actual contraction scour used as a reference value for abutment scour rather than the idealized long contraction scour. Finally, it can be observed in Figure 5 that a comparison of the mean depth ratios for submerged and overtopping flows with those for free-surface flows indicates a significant amount of additional scour caused by vertical flow contraction due to submergence and overtopping relative to lateral flow contraction in free-surface flow.

The location of the maximum abutment scour was found to be opposite the downstream edge of the abutment face between the first two pier bents starting from the embankment toe; that is, it was under the bridge deck. Its location was fairly consistent for all three types of flow considered in this study. Further research is continuing on this aspect of the problem.

\section{CONCLUSIONS}

A physical model study of inundation of a bridge embankment that terminates in the floodplain of a compound channel showed that lateral flow contraction, vertical flow contraction, and local turbulence effects all contribute to scour in the vicinity of the abutment. Scour at first increased in transitioning from submerged orifice flow to mild deck submergence but then decreased as the degree of submergence became more pronounced. This suggests that scour design procedures should include consideration of several overtopping cases in addition to submerged orifice flow. Using the procedures described in this paper, abutment scour is shown to be a combination of lateral and vertical flow contraction effects in addition to local scour influences and can be computed as a multiple of the contraction component of scour in the cases of submerged and overtopping flows as well as free-surface flows. Additional data are needed to confirm this relationship for a wider range of embankment lengths and flow contraction ratios.

\section{ACKNOWLEDGMENTS}

This research was partially supported by the Georgia Department of Transportation.

\section{REFERENCES}

Ettema, R., Yorozuya, A., Muste, M., and Nakato, T. (2006). "Design estimation of abutment scour depths." Proceedings Third International Conference on Scour and Erosion, CURNET, Gouda, The Netherlands.

Ettema, R., Nakato, T., Yorozuya, A., and Muste, M. (2008). "Three abutment scour conditions investigated with laboratory flume." Proceedings Fourth International Conference on Scour and Erosion, Chuo University, Tokyo, Japan. 
Hong, S., Gotvald, A., Sturm, T. W., Landers, M. (2006). "Laboratory and field measurements of bridge contraction scour." Proceedings Third International Conference on Scour and Erosion, CURNET, Gouda, The Netherlands.

Laursen, E.M. (1963). "An analysis of relief bridge scour." J. Hydr. Div., ASCE, 92(HY3), 93-118.

Lee, Seung Oh, Sturm, T. W., Gotvald, A., and Landers, M. (2004). "Comparison of laboratory and field measurements of bridge pier scour." Proceedings Second International Conference on Scour and Erosion, ed. by Y. M. Chiew, S. Y. Lim, and N. S. Cheng, Singapore, 231-239.

Lee, Seung Oh, and Sturm, T. W. (2009). "Effect of sediment size scaling on physical modeling of bridge pier scour.” J. Hydraul. Engrg., ASCE, 135(10), 793-802.

Morris, J.L., and Pagan-Ortiz, J.E. (1999). "Bridge scour evaluation program in the United States." Stream Stability and Scour at Highway Bridges, E.V. Richardson and P.F. Lagasse, eds., ASCE, 61-70.

Parola, A. C., Hagerty, D. J., and Kamojjala, S. (1998). Highway infrastructure damage caused by the 1993 upper Mississippi River basin flooding. NCHRP Report 417, Transportation Research Board, Washington, DC.

Richardson, E. V., and Davis, S. R. (2001). Evaluating scour at bridges. HEC-18, U.S. Federal Highway Administration, Washington, DC.

Stamey, Timothy C. (1996). Summary of data-collection activities and effects of flooding from Tropical Storm Alberto in parts of Georgia, Alabama, and Florida, July 1994. U.S. Geological Survey Open-File Report 96-228, 23p.

Sturm, T.W. (1999). "Abutment scour studies for compound channels." Report FHWA-RD-99-156, U.S. Dept. of Transportation, Federal Highway Administration, Washington, D.C.

Sturm, Terry W. (2006). "Scour Around Bankline and Setback Abutments in Compound Channels," J. Hydraul. Engrg., ASCE, 132(1), 2006, 21-32. 